$$
\begin{array}{ccccccc}
\text { L } & \text { E } & \text { T } & \text { u } & \text { v } & \text { O } & \text { s } \\
\hline \text { ARCHEOlogija } & 46
\end{array}
$$


Lietuvos istorijos institutas

\begin{tabular}{llllllll}
$\mathrm{L}$ & $\mathrm{I}$ & $\mathrm{E}$ & $\mathrm{T}$ & $\mathrm{U}$ & $\mathrm{V}$ & $\mathrm{O}$ & $\mathrm{S}$ \\
\hline
\end{tabular}

ARCHEOlogija 46 


\section{Leidybą finansavo}

\section{LIETUVOS MOKSLO TARYBA}

PAGAL VALSTYBINĘ LITUANISTINIŲ TYRIMŲ IR SKLAIDOS 2016-2024 METŲ PROGRAMĄ

(Finansavimo sutarties numeris S-LIP-19-4)

\section{Redaktorių kolegija / Editorial board:}

Atsakingoji redaktorė / Editor-in-chief dr. Agnè Čivilytė (Lietuvos istorijos institutas, Vilnius / Lithuanian Institute of History, Vilnius)

Atsakingosios redaktorès pavaduotoja / Assistant Editor dr. Elena Pranckènaitè (Lietuvos istorijos institutas, Vilnius / Lithuanian Institute of History, Vilnius)

Dr. Laurynas Kurila (Lietuvos istorijos institutas, Vilnius / Lithuanian Institute of History, Vilnius)

Dr. Valdis Bērziņš (Latvijos universitetas, Latvijos istorijos institutas, Ryga / University of Latvia, Institute of Latvian History, Riga)

Habil. dr. Anna Bitner-Wróblewska (Valstybinis archeologijos muziejus Varšuvoje, Lenkija / State Archaeological Museum in Warsaw, Poland)

Dr. Christoph Jahn (Baltijos ir Skandinavijos archeologijos centras, Šlèzvigas, Vokietija / Center for Baltic and Scandinavian Archaeology, Schleswig, Germany)

Prof. dr. Rimantas Jankauskas (Vilniaus universitetas, Lietuva / Vilnius University, Lithuania)

Akad. prof. dr. Eugenijus Jovaiša (Lietuvos mokslu akademija, Vilnius / Lithuanian Academy of Sciences, Vilnius)

Habil. dr. Bartosz Kontny (Varšuvos universitetas, Archeologijos fakultetas, Lenkija / Faculty of Archaeology, University of Warsaw, Poland)

Prof. dr. Valter Lang (Tartu universitetas, Estija / University of Tartu, Estonia)

Doc. dr. Algimantas Merkevičius (Vilniaus universitetas, Lietuva / Vilnius University, Lithuania)

Habil. dr. Tomasz Nowakiewicz (Varšuvos universitetas, Archeologijos fakultetas, Lenkija / Faculty of Archaeology, University of Warsaw, Poland)
Habil. dr. Grzegorz Osipowicz (Mikalojaus Koperniko universitetas, Torunè, Lenkija / Nicolaus Copernicus University, Toruń, Poland)

Dr. Gytis Piličiauskas (Lietuvos istorijos institutas, Vilnius / Lithuanian Institute of History, Vilnius)

Dr. Eve Rannamäe (Tartu universtitetas, Estija / University of Tartu, Estonia)

Dr. Andra Simniškyte (Lietuvos istorijos institutas, Vilnius / Lithuanian Institute of History, Vilnius)

Dr. Roberts Spirgis (Latvijos universitetas, Latvijos istorijos institutas, Ryga / University of Latvia, Institute of Latvian History, Riga)

Dr. Eugenijus Svetikas (Lietuvos istorijos institutas, Vilnius / Lithuanian Institute of History, Vilnius)

Dr. Andris Šnē (Latvijos universitetas, Ryga / University of Latvia, Riga)

Doc. dr. Gintautas Zabiela (Klaipédos universitetas, Lietuva / Klaipeda University, Lithuania)

Prof. dr. Šarūnas Milišauskas (Niujorko valstijos Bafalo universitetas, JAV / New York State University at Buffalo, USA)

Prof. dr. Timothy Chevral (Niujorko valstijos Bafalo universitetas, JAV / New York State University at Buffalo, USA)

Prof. dr. Johan Ling (Gioteborgo universitetas, Švedija / University of Gothenburg, Sweden)

Sekretorè / Secretary Dovilè Urbonavičiūtè-Jankauskienė

Redakcijos adresas / Editorial Board address:

Lietuvos istorijos institutas, Archeologijos skyrius

Kražių g. 5, LT-01108 Vilnius

Tel. (+370) 5 2614935, fax (+370) 52611433

e-mail: lietuvosarcheologija@gmail.com;

civilytea@gmail.com

\section{Žurnalas registruotas: EBSCO Publishing: Central and Eastern European Academic Source European Reference Index for the Humanities and Social Sciences (ERIH PLUS)}




\section{TURINYS / CONTENT}

Agnè Čivilytè

Agnè Čivilytè

Jonas Beran

Gabrielè Gudaitienè

Andreas Kotula, Henny Piezonka, Thomas Terberger

Vygandas Juodagalvis

Eglè Šatavičè

Grzegorz Osipowicz, Justyna Orłowska, Gytis Piličiauskas, Giedrẻ Piličiauskienė, Mariusz Bosiak

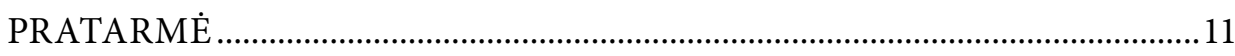

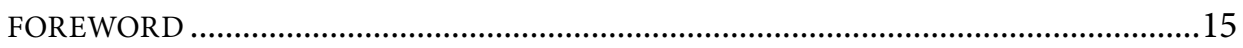

RUDENS POPIETĖ SU RIMUTE RIMANTIENE _.............................................19

AUTUMN AFTERNOON WITH RIMUTE் RIMANTIENĖ

GREETINGS FROM OLD CENTRAL-EASTERN GERMANY:

MEMORIES OF INTERESTING TIMES .27

LINKĖJIMAI IŠ PIETRYČIŲ VOKIETIJOS: PRISIMINIMAI APIE ĮDOMIUS LAIKUS

\section{STRAIPSNIAI / ARTICLES}

EIGULIAI, ONE OF RIMUTE் RIMANTIENĖ'S FIRST EXCAVATIONS A REVISED INTERPRETATION .33

EIGULIAI - VIENA PIRMŲJŲ RIMUTĖS RIMANTIENĖS KASINĖJIMŲ VIETŲ.

NAUJA INTERPRETACIJA

THE MESOLITHIC CEMETERY OF GROß FREDENWALDE (NORTH-EASTERN GERMANY) AND ITS CULTURAL AFFILIATIONS.......65 GROS FREDENVALDE (ŠIAURĖS RYTŲ VOKIETIJA) MEZOLITO LAIKOTARPIO KAPINYNAS IR JO KULTÜRINĖS SĄSAJOS .83

AKMENINIAI GLUDINTI KIRVIAI LIETUVOJE. TIPOLOGIJOS IR TERMINOLOGIJOS PROBLEMOS .85 GROUND STONE AXES IN LITHUANIA. PROBLEMS OF TYPOLOGY AND TERMINOLOGY 108

NEOLITHIC SOCIETIES AND THEIR POTTERY IN SOUTH-EASTERN LITHUANIA 111 NEOLITO BENDRUOMENĖS IR JỤ KERAMIKA PIETRYČIỤ LIETUVOJE. 142

OSSEOUS POINTS AND HARPOON HEADS FROM ŠVENTOJI SUBNEOLITHIC SITES, COASTAL LITHUANIA. FIRST TRACEOLOGICAL INSIGHT INTO THE WAY THEY WERE PRODUCED AND USED 147

KAULINIAI ANTGALIAI IR ŽEBERKLAI LIETUVOS PAJÜRIO ŠVENTOSIOS SUBNEOLITINĖSE GYVENVIETĖSE: GAMYBA IR NAUDOJIMAS PIRMU巳JŲ TRASOLOGINIŲ TYRIMỤ DUOMENIMIS 168 
Sławomir Kadrow

Frédéric Surmely

Rokas Vengalis, Jonas Volungevičius, Gintautas Vèlius, Albinas Kuncevičius, Justina Poškienè, Regina Prapiestienè

Andra Simniškytè

Inga Merkyte்

Rokas Vengalis
MACRO AND MICRO SCALE NEOLITHISATION PROCESSES IN SOUTH-EASTERN POLAND AGAINST THE BACKGROUND OF CENTRAL-EASTERN EUROPE 171

PIETRYČIŲ LENKIJOS NEOLITIZACIJOS PROCESAI MIKRO- IR MAKROLYGMENIMIS VIDURIO IR RYTŲ EUROPOS KONTEKSTE 187

CHARACTERIZATION OF TERTIARY FLINTS BY GEOCHEMISTRY: APPLICATION TO THE FRENCH TERRITORY.

TERCIARO TITNAGO PRANCÜZIJOS TERITORIJOJE CHARAKTERIZAVIMAS NAUDOJANT GEOCHEMINI METODĄ

ŽMOGUS PRIEŠ GAMTĄ: RELJEFO TRANSFORMAVIMAS İRENGIANT XIII-XIV A. KERNAVÉS PILI IR JO SUKELTI EROZINIAI PROCESAI ....... 207 MAN AGAINST NATURE: THE TRANSFORMATION OF THE RELIEF DURING THE CONSTRUCTION OF KERNAVĖ CASTLE IN THE $13^{\mathrm{TH}}-14^{\mathrm{TH}}$ CENTURIES AND THE EROSIONAL PROCESSES IT CREATED 248

KUPIŠKIO (AUKŠTUPĖNŲ) PILIAKALNIS: TEORINĖS PRIELAIDOS

IR TYRIMŲ REZULTATAI .255

HILLFORT OF KUPIŠKIS (AUKŠTUPĖNAI): THEORETICAL ASSUMPTIONS AND INVESTIGATION RESULTS 284

\section{KITAIP APIE ARCHEOLOGIJA /} ALTERNATIVE PERCEPTIONS OF ARCHAEOLOGY

Šarūnas Radvilavičius

KELIAUTOJO LAIKU UŽRAŠAI. 289

THE NOTEBOOK OF TIME TRAVELLER

\section{DISKUSIJOS / DISCUSSIONS}

STUDIES OF ANCIENT DNA. THE RACE FOR THE ULTIMATE ANSWER .293

SENOVĖS DNR TYRIMAI: KARŠTLIGIŠKOS ATSAKYMŲ PAIEŠKOS

\section{RECENZIJOS / REVIEWS}

ALGIMANTAS MERKEVIČIUS (SUD.), 2018. ANKSTYVOJO METALŲ LAIKOTARPIO GYVENVIETÉS LIETUVOJE (SETTLEMENTS OF EARLY METAL PERIOD IN LITHUANIA). 305

INFORMACIJA APIE PROJEKTUS / INFORMATION ABOUT THE PROJECTS 309

AUTORIŲ DĖMESIUI. 327 GUIDELINES FOR AUTHORS 


\title{
THE MESOLITHIC CEMETERY OF GROß FREDENWALDE (NORTH-EASTERN GERMANY) AND ITS CULTURAL AFFILIATIONS
}

\author{
ANDREAS KOTULA ${ }^{1}$, HENNY PIEZONKA ${ }^{2}$, THOMAS TERBERGER ${ }^{3}$
}

\begin{abstract}
${ }^{1}$ Seminar für Ur- und Frühgeschichte, Georg-August-Universität Göttingen, Nikolausberger Weg 15, 37073, Göttingen, e-mail: andreas.kotula@posteo.de

${ }^{2}$ Institut für Ur- und Frühgeschichte, Christian-Albrechts-Universität Kiel, Johanna-Mestorf-Str. 2-6, 24118, Kiel, e-mail: hpiezonka@ufg.uni-kiel.de

${ }^{3}$ Niedersächsisches Landesamt für Denkmalpflege, Scharnhorststr. 1, 30175, Hannover / Seminar für Ur- und Frühgeschichte, Georg-August-Universität Göttingen, Nikolausberger Weg 15, 37073, Göttingen, e-mail: thomas.terberger@phil.uni-goettingen.de
\end{abstract}

The site of Groß Fredenwalde was discovered in 1962 and has been known as a Mesolithic multiple burial since ${ }^{14} \mathrm{C}$-dates verified an early Atlantic age in the early 1990s. New research since 2012 reconstructed the situation of the poorly documented rescue excavation in 1962 and identified six individuals from at least two separate burials. The new excavations uncovered more burials and Groß Fredenwalde stands out as the largest Mesolithic cemetery in North Central Europe and the oldest cemetery in Germany. In this paper the known burial evidence from this site is presented and the location of the cemetery, mortuary practices, and grave goods are discussed in a broader European context. Northern and Eastern connections appear especially tangible in Groß Fredenwalde and it is suggested that the community associated with the Groß Fredenwalde Mesolithic cemetery was integrated into wider cultural networks connected to the North and East.

Keywords: Mesolithic burials, Mesolithic networks, East-West contacts, mortuary practices, grave goods.

Gros Fredenvale kapinynas buvo atrastas 1962 metais. 1990 m. grupiniai kapai radioaktyviosios anglies metodu buvo datuoti mezolito laikotarpiu (ankstyvuoju atlančiu). Nuo $2012 \mathrm{~m}$. vykdomi archeologiniai tyrimai padejo rekonstruoti menkai dokumentuotu 1962 m. gelbejjimo darbu situacija ir nustatè šešis asmenis iš mažiausiai dviejų atskirų palaidojimų. Atlikus kasinèjimus, buvo aptikta ir daugiau palaidojimų.

Gros Fredenvale išsiskiria kaip didžiausias mezolito laikotarpio kapinynas šiaurès vidurio Europoje ir seniausias kapinynas Vokietijoje. Šiame straipsnyje pristatoma kapu medžiaga, o informacija susijusi su kapinyno vieta, laidojimo tradicijomis ir ịkapemis, aptariama atsižvelgiant ị platesnį europinị kontekstą. Ryšiai tarp šiaurès ir rytu ypač aiškiai apčiuopiami Gros Fredenvale kapinyne, todèl teigiama, kad šis mezolito laikotarpio kapinynas buvo dalis kultūrinio tinklo, jungiančio Šiaurę ir Rytus.

Reikšminiai žodžiai: mezolito kapai, mezolito ryšiai, Rytų-Vakarų kontaktai, laidojimo tradicijos, ¡kapès.

\section{INTRODUCTION}

In Central Europe, research on the MesolithicNeolithic transition is often dominated by discussions on the Neolithisation process, with late hunter-gatherers and Linear Pottery Culture farmers seen as the prominent agents. During the last decade, this debate has been pushed forward by palaeogenetic evidence which supports the idea of early farmers colonizing Central Europe by c. 5 500-5 400 cal вС 
(e.g. Bramanti et al. 2009; Hofmanová et al. 2016; Czekaj-Zastawny et al. 2020). The Neolithisation process in the western Baltic setting in c. 4200-4 000 cal BC was probably more complex and it is a matter of debate as to what extent migrating farmers might have been responsible for the gradual introduction of farming into northern Germany and southern Scandinavia at that time (e.g. Hartz et al. 2007; Müller 2011; Sørensen, Karg 2014; Sørensen 2014; Terberger et al. 2018).

Less attention has been paid to the cultural and technological affiliations of late hunter-gathererfishers of Central Europe to neighbouring regions in general and to the east in particular. This latter shortcoming is especially due in part to language constraints and increasingly separated research traditions in the later $20^{\text {th }}$ century, which has largely inhibited scientific dialogue across borders and political systems. At the same time, archaeological schools prevailing in Central and Western Europe in a somewhat evolutionist way tended to emphasize the influence of the more 'advanced' Neolithic communities as opposed to simpler, less innovative hunter-gatherer groups. Innovations such as the introduction of pottery in Ertebølle contexts of the western Baltic by c. 4700 cal BC were explained as the result of contacts with southern farming communities by scholars such as H. Schwabedissen (1994); that this might have been a hunter-gatherer technology in its own right was not seen as an option.

Rimutè Rimantienè was one of the few scholars at that time who had a wide perspective encompassing both Eastern and Central Europe and she was the one to introduce evidence from the Eastern Baltic into the wider discussion. Her comprehensive overview on the Stone Age of Lithuania (Rimantienè 1994) is still a central publication for all those striving to better understand the Stone Age in the Baltic region and the East-West contacts.

In our contribution we want to take this legacy of Rimutè Rimantienè as a starting point to review the cultural affiliations reflected in the burial site of Groß Fredenwalde, Brandenburg (NE Germany). Contextualizing our findings within the wider geographical frame, the results contribute to the evaluation and better understanding of the EastWest contacts in the Baltic Sea region during the Mesolithic.

\section{THE BURIAL SITE OF GROß FREDENWALDE}

Groß Fredenwalde is located at the top of Weinberg hill next to the village of Groß Fredenwalde in Uckermark (Fig. 1). In 1962, the erection of a sign post on this prominent landmark led to the discovery of skeletal remains (Schoknecht 1963; Gramsch, Schoknecht 2003). Initially, local policemen inspected the site and the same day an amateur collected human bones and some grave goods (complex I). The next day, archaeologist Schoknecht excavated two further skeletons (complex II). A simple drawing shows the inhumation of an adult, probably female, with the skeleton of a child on her abdomen.

Schoknecht (1963) interpreted the ochre-stained skeletons and the few associated animal tooth pendants as the remains of a Neolithic multiple burial. Later, Brinch Petersen (1988) suggested a Mesolithic date for the finds in his publication of the multiple burial of Strøby Egede on Zealand (Denmark) which he dated to the middle Ertebølle culture (c. 4800 cal вс). Some years later a Mesolithic date was confirmed for the Groß Fredenwalde remains by first radiocarbon dates (Hedges et al. 1995). They assigned the individuals to an early Atlantic context (c. $6500-$ $6300 \mathrm{cal} \mathrm{BC}$ ). A thorough re-assessment of the 1962 rescue excavation and its results was published by Gramsch and Schoknecht (2003) and later Gramsch provided a comparative discussion of the site within its wider East German framework (2016).

New research started in 2012, during which the 1962 construction pit was re-excavated step by 


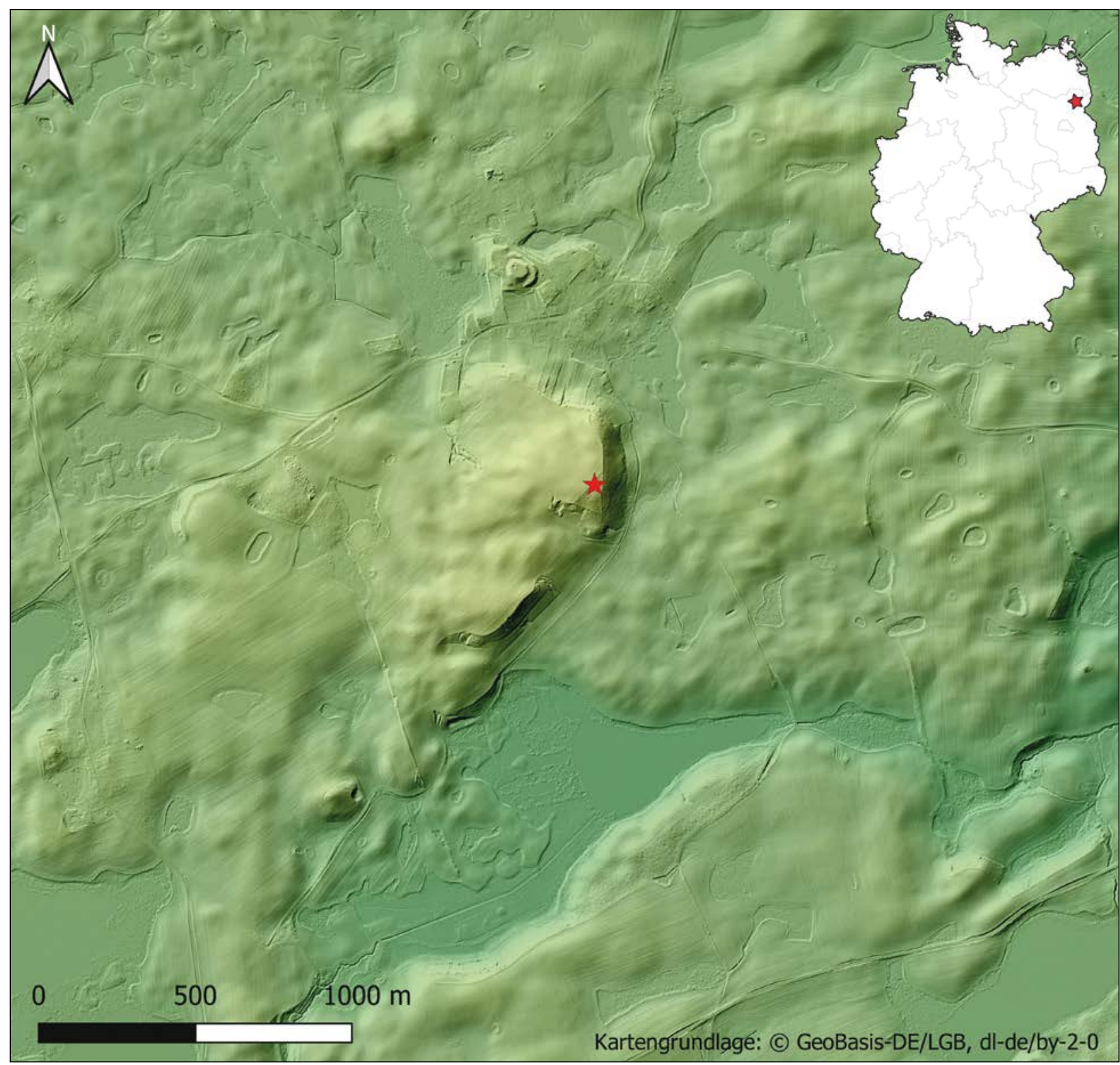

Fig. 1. Location of the Groß Fredenwalde site in the landscape of Uckermark (Brandenburg, NE-Germany). Drawing by A. Kotula.

step. A systematic analysis of the human remains found in 1962 allowed for the identification of six individuals (Jungklaus et al. 2016). The skeletal remains from 1962 had become mixed up after the rescue excavation and only part of the bones could be reliably assigned to specific individuals. Altogether, three adults, (Komma) two male and one female (individuals 1-3) as well as three children (individuals 4-6) were identified. Grave goods associated with the 1962 burials included about 31 flint blades, two transverse arrowheads, fragments of a slotted bone dagger, and 86 animal tooth pendants (Gramsch, Schoknecht 2003; Terberger et al. 2015). Five animal tooth pendants were still attached to a skull at the time of discovery; they can be attributed to the headdress of a 3-4 year-old 


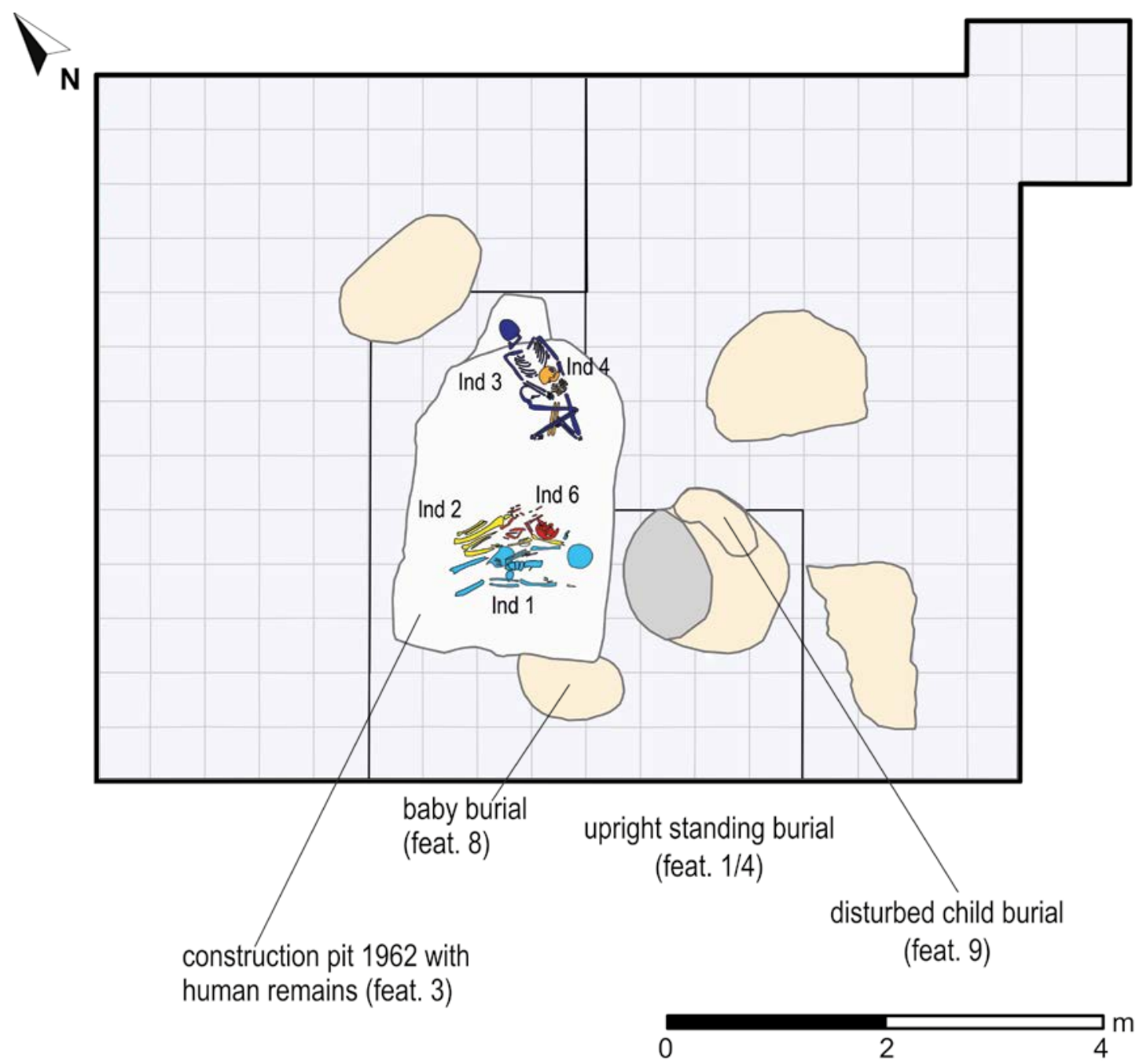

Fig. 2. Groß Fredenwalde. Plan of the excavation with different features including the 1962 burials (complex I and II). Drawing by A. Kotula.

child (individual 6). The bone dagger as well as most of the flint blades and two transverse arrowheads might have been connected to one of the males (individuals 1 or 2). Three more animal tooth pedants were lying close to the skull and another four near the leg bones of the female (individual 3) who was excavated on the second day in 1962 with a child on her abdomen (probably individual 4). A bone pin was associated with this inhumation. The ${ }^{13} \mathrm{C}-/{ }^{15} \mathrm{~N}$-values of all six individuals suggest a regular intake of aquatic resources (Terberger et al. 2015; 2018).
Photographs found in the archive of the State Service for Cultural Heritage of Brandenburg recently allowed for a more comprehensive understanding of the situation discovered in 1962. Gramsch and Schoknecht (2003) interpreted the finds as a single multiple burial (see also Gramsch 2016). However, freshly interpreted archival information in combination with systematic radiocarbon dating results suggest the situation originally found in the pit during rescue excavation in 1962 was more complex (Terberger et al. in press): 1) The double burial of a man (individual 2) with flexed legs and a young child 


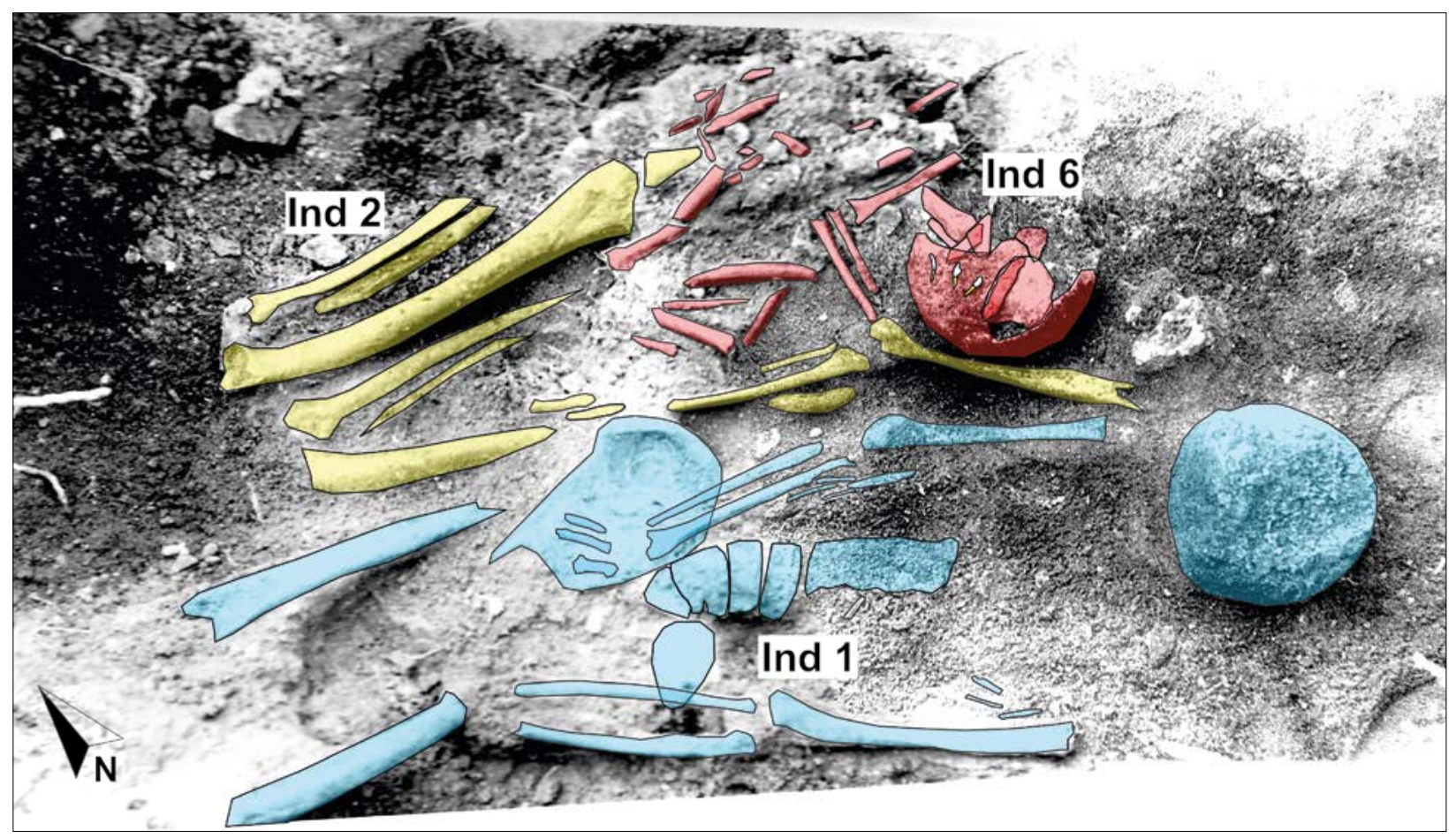

Fig. 3. Remains of individuals (complex I) marked on the photo made in 1962 on the first day of the discovery. Photo by Brandenburgisches Landesamt für Denkmalpflege; modified by A. Kotula.

lying on his abdomen (individual 6) is visible on the photo (Fig. 2-3). These individuals have been dated to c. $6200-6000$ cal вс. $^{12}$ ) The man in the supine position (individual 1) is lying right beside individual 2. A direct date of c. 5900-5 730 cal BC might indicate a slightly later context for this burial event, although differences in the age offsets connected to the reservoir effects of the neighbouring individuals (no. 1 and 2) could also be responsible for the considerable dating difference. 3) The 7-8 year-old child (individual 5) is not present on the photos or the drawing of the second day. It might belong to the double burial mentioned before, but it seems also possible that a separate child burial dated to c. 6 100-6 $000 \mathrm{cal} \mathrm{BC}$ was destroyed on the first day of the rescue excavation. 4) About $1 \mathrm{~m}$ to the east of the described inhumation (= complex I), the double burial of a woman and a child was found (individuals 3-4; complex II), showing a somewhat different orientation. Radiocarbon dates suggest a slightly younger context of c. 6 100-5840 cal BC for this double burial.

In conclusion, according to this new interpretation of the remains found in 1962, we are dealing with at least two separate multiple burials, complex I and complex II, which are clearly separated spatially and which are also distinguished by their different orientation (Fig. 2). A male (individual 1) in complex I provided a slightly younger radiocarbon age than the other individuals of this complex, which could either be due to inconsistent reservoir age offsets between the individuals, or due to a separate, later inhumation.

\footnotetext{
${ }^{1}$ Some reservoir effects should be expected for the AMS dates of human bones and therefore only estimates can be given here for the dating. The AMS-dates of the two animal tooth pedants were the most reliable and provided almost identical dates of c. 5970 cal вс (Terberger et al. 2015). For a discussion of reservoir effects in human bone dates from northern Germany see e.g. Olsen et al. 2010; Fernandes et al. 2015.
} 


\section{NEW RESEARCH REVEALS THE LARGEST CEMETERY ON THE CENTRAL EUROPEAN PLAIN}

The results of the re-assessment suggest that probably two or three burials with six individuals dating to the period from c. 6200 to $5730 \mathrm{cal} \mathrm{BC}^{2}$ were discovered in 1962. Ongoing new research confirms that the discoveries of 1962 do not stand alone but are part of a larger burial site with further individuals and more complex burials (Terberger et al. 2015). Directly neighbouring the original 1962 pit, the burial of a small child about one year old was found in red-stained sands (feature 8). According to a radiocarbon date of c. $6430 \mathrm{cal} \mathrm{BC}$, it might be somewhat older than the inhumations mentioned before (Jungklaus, Terberger 2016).

Most interesting is another burial complex with two individuals interred with a time difference of roughly 1000 years. Initially, a roughly 8-9 year-old child (feature 9) was buried around 5940 cal BC. Most of this burial was destroyed by the later burial of a roughly 25 year-old man, which left only the bones of the right foot of the child in their original position. The later inhumation (feature 1/4) in a pit about 1.6 $m$ deep was placed directly through the older burial. During the excavation, the first feature identified was a fire place directly below the plough horizon. Underneath this fire place, most of the human bones were found in a mixed position (Fig. 4). Only parts of the spine and the leg bones had remained in or close to their anatomically correct position (Fig. 5; Terberger et al. 2015). The interpretation of the feature suggests a sequential burial rite: In a first step, the body of the man was apparently placed in an almost upright position, only the lower part of the pit around the legs being filled with sand. Some gnaw marks from scavengers on two arm bones as well as the missing left ulna and radius indicate that the burial pit had remained unsealed or preliminarily sealed for a while. This is supported by the observation that the skull and further bones of the upper body had fallen into the pit after decomposition. Only the leg bones had remained more or less close to their original upright position, although the knees were bent to the backside. In a further step, the burial was then filled in and sealed by a fire lit on top of the pit, directly above the skull. Grave goods such as two truncated blade knifes, 32 flint blades, a small hammer stone, and two bone pins were found intermixed with the bones. While the other burials show evidence of the use of red ochre in the burial rite, no red-stained sands were associated in this young male's unusual burial. An AMS date for a bone sample from this individual dates this burial to c. $5100 \mathrm{cal} \mathrm{BC.} \mathrm{An}$ elevated ${ }^{15} \mathrm{~N}$-value of $11.3 \%$ renders aquatic reservoir effects possible in connection with this date and the two dates for charcoal samples from the fire place are probably more reliable. They indicate a date of c. $4900 \mathrm{cal} \mathrm{BC}$ for this burial (Terberger et al. 2015).

Recently, further features were detected at Groß Fredenwalde and work is in progress to document these new burials. In summary, more than ten human individuals in a minimum of eight burials can currently be assigned to the cemetery. According to the radiocarbon dates, the main phase of the burial site covers a period from c. 6400 to $5800 \mathrm{cal} \mathrm{BC}$. Most of the AMS dating samples stem from human bones and if aquatic reservoir effects of up to a couple of hundred years are taken into consideration, the true age of the period of the cemetery's use might have been somewhat later and shorter. Further AMS dates of grave goods, especially from the closed burial contexts, are planned in order to better address this problem

\footnotetext{
${ }^{2}$ This chronology is based on radiocarbon dates not corrected for reservoir effects; the true age of the burial events might be younger. However, the two dates from the animal tooth pedants prove the presence of burial activities around $6000 \mathrm{cal} \mathrm{BC}$ (see footnote 1; Terberger et al. 2015).
} 


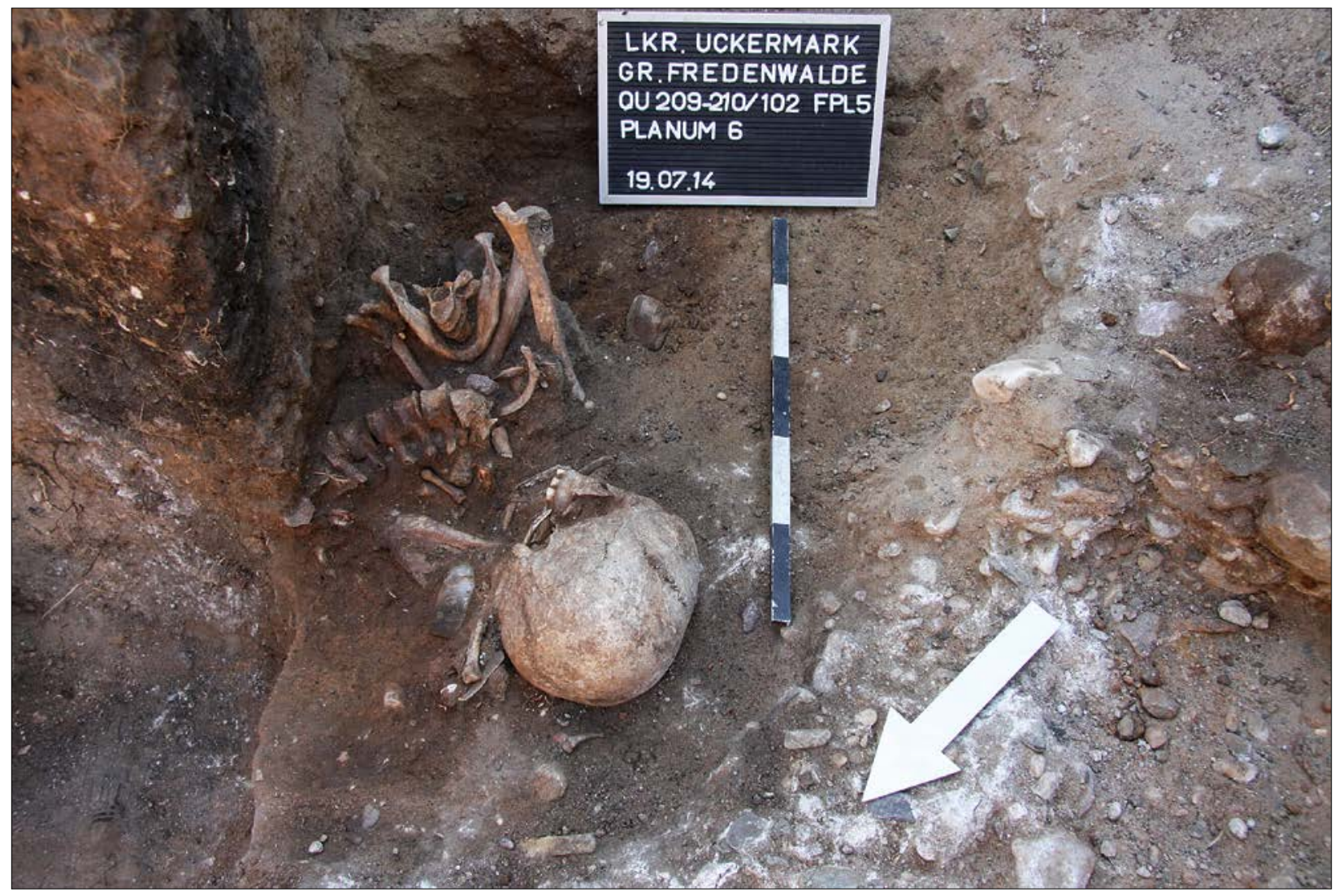

Fig. 4. Groß Fredenwalde. Feature 1/4 with the human remains of a young male roughly 25 years old in a mixed position under a fire place. Photo by A. Kotula.

by pairing the dates from the human remains and the terrestrial animal bones. The burial of the young male interred in an upright position (feature 1/4), however, can be safely attributed to a more recent phase (c. 4900 cal BC), a period when early Linear Pottery Culture farmers had already founded settlements in the vicinity.

Linear Pottery Culture finds and settlements a few kilometres to the northeast of Weinberg prove that the local fertile soils attracted early farming communities and from c. $5200 \mathrm{cal} \mathrm{BC}$ on, late huntergatherer-fishers probably lived parallel to and in contact with colonizing early farmers in this region (Ismail-Weber 2017). It is therefore likely that the young man buried in an upright position (feature 1/4) c. $4900 \mathrm{cal} \mathrm{BC}$ had had personal contact with members of the early farming communities. His ${ }^{15} \mathrm{~N}$ isotopic value, however, corresponds to the values of the Mesolithic individuals buried at this site roughly 1000 years earlier, which indicate regular consumption of fresh water resources. The presence of his burial in an old Mesolithic cemetery might also indicate that his community was aware of the former meaning of the site and was rooted in a hunter-gatherer-fisher way of life.

The water rich environment of Havelland and Uckermark must have been attractive for the Mesolithic population. At the same time, fertile soils along the lower Oder provided suitable conditions for early farming communities. Against this background there are excellent conditions to study the relationship of these very different life styles at a time before and after Neolithisation.

In the supraregional context of the Mesolithic burial record, Groß Fredenwalde stands out due 


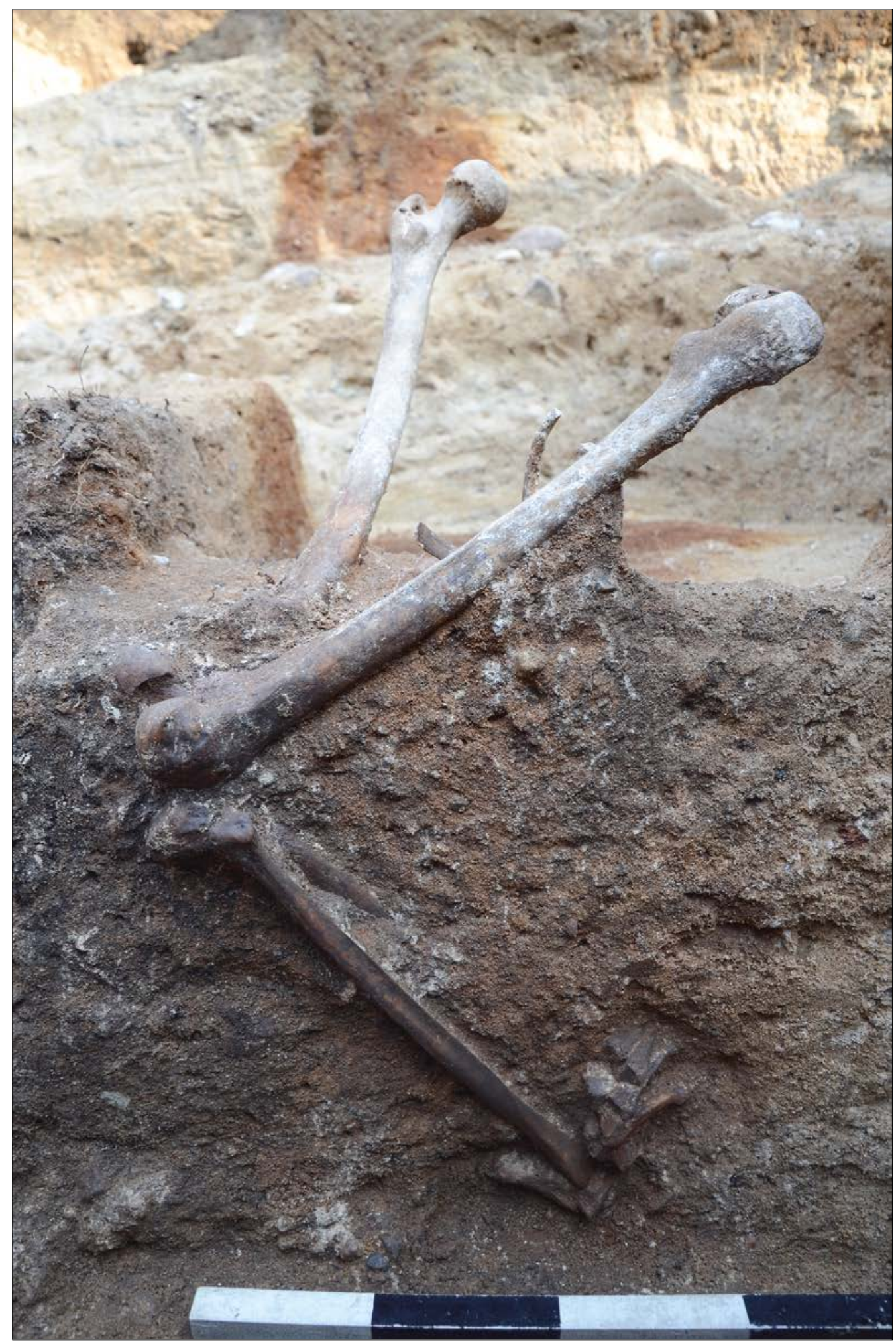

Fig. 5. Groß Fredenwalde. Feature 1/4 with the leg bones of the young male close to their correct anatomical position. Photo by T. Terberger. 


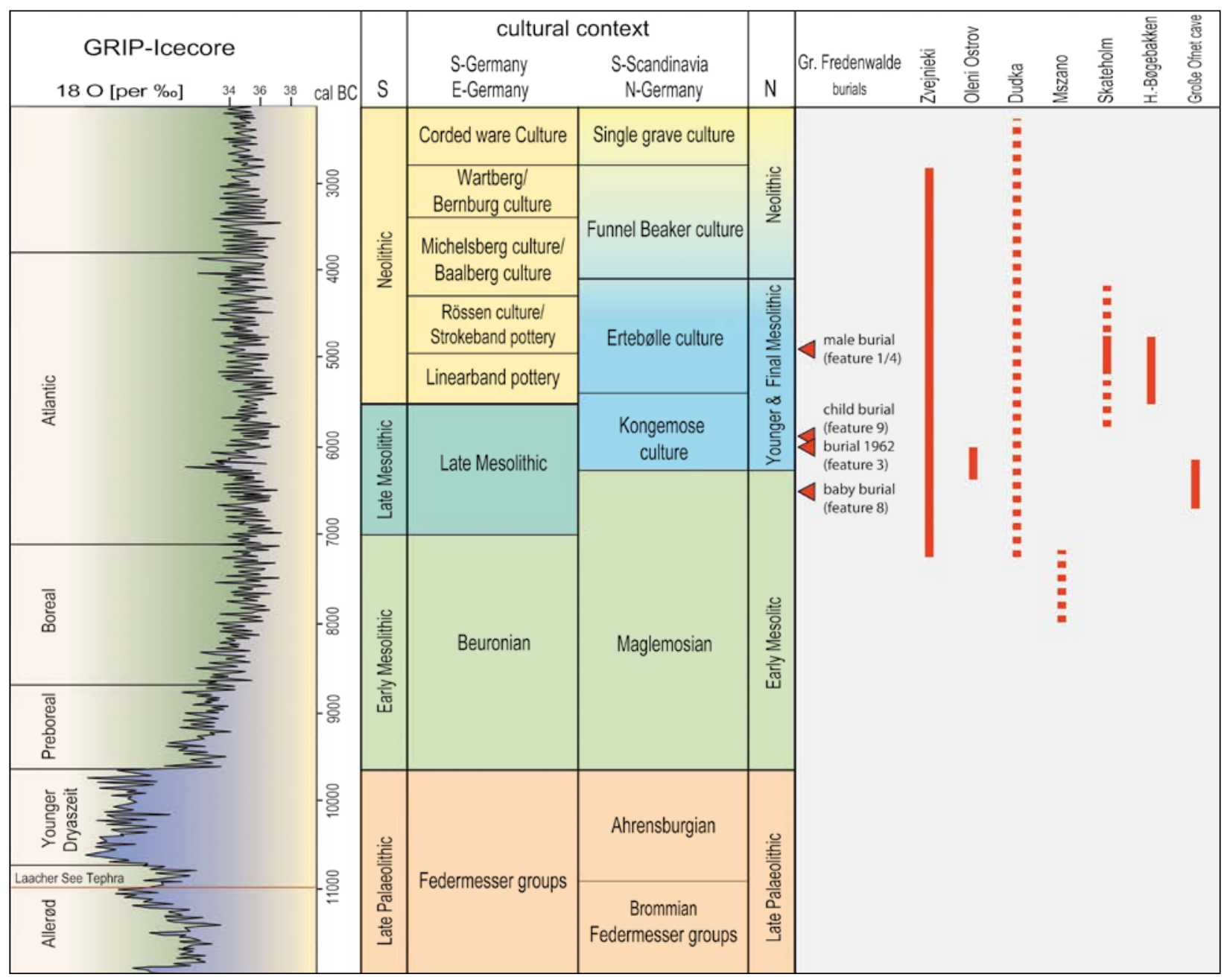

Fig. 6. Chronology of the Mesolithic-Neolithic in North Central Europe with the dating of Groß Fredenwalde and other important burial sites. Solid line: dated by a series of radiocarbon dates; dotted line: estimated period by isolated radiocarbon dates or other evidence. Compiled by T. Terberger and A. Kotula.

to its considerable number of inhumations. The evidence from Eastern Europe suggests a tradition of Mesolithic cemeteries starting in the early Mesolithic, while most of the Mesolithic cemeteries in Scandinavia are dated younger (Fig. 6). Although even the term cemetery has been challenged for burials in settlements like Henriksholm-Bøgebakken, the general picture is biased by the better visibility of younger Mesolithic sites in Scandinavia (Brinch Petersen 2015, p. 159). From Central Europe very few candidates for Mesolithic cemeteries can be mentioned; Groß Fredenwalde provides the largest burial population among them. Only the Große Ofnet cave in Bavaria, Southern Germany, where the heads of more than 30 individuals dating to the early Atlantic were deposited, shows a larger number of Mesolithic individuals. Some of the skulls show signs of trauma (Orschiedt 2015) and it is a matter of discussion if these skulls represent the remains of the regular inhumations of a group. It might well be the case that the skulls were the victims of a single violent event and cannot be considered a true cemetery.

No Mesolithic inhumation burial site in Germany besides Groß Fredenwalde has yielded more than 
four individuals. A recent re-examination of four individuals from Bottendorf in Thuringia revealed that one skeleton from a presumed 'double burial' in fact dates to the Bronze Age (Grünberg et al. 2016). The site of Mszano (Poland) located east of the river Vistula yielded six individuals from five burials with traces of cremation (Marciniak 2001). Due to the poor bone preservation, only samples from the burnt wooden structures of the burial features could be radiocarbon dated and suggested a Mesolithic context in the Boreal period. If the dates can be accepted as also valid for the burials themselves, then the site should be considered the oldest cemetery in Central Europe. Two child burials from Bettenroder Berg, Lower Saxony, suggest a need to be cautious with the indirect dating of such skeletons: each of the burials was originally assigned to the Mesolithic on the basis of a radiocarbon date for charcoal samples from the burial pits. Direct dating of the two skeletons later assigned the two burials to an Iron Age context (Grote, Terberger 2011). According to Meiklejohn et al. (2009), a Mesolithic cemetery should be represented by a minimum of nine individuals. Using this definition, Groß Fredenwalde is the largest and probably oldest cemetery in Central Europe.

\section{GROß FREDENWALDE WITHIN WIDER LATE MESOLITHIC NETWORKS}

\section{The cemetery and its location}

The Mesolithic cemetery at Groß Fredenwalde is part of a wider phenomenon of the intensified occurrence of formal disposal areas of mortuary remains, i.e. cemeteries, observable across Europe in the Later Mesolithic. This phenomenon extends from the Atlantic coast (cemeteries of the Muge estuary, Portugal; Téviec and Hoëdic, Brittany) across South-Eastern Europe (cemeteries at the Iron Gates Danube gorge, Serbia, and Romania), and Southern Scandinavia (e.g., Vedbæk-Bøgebakken, Denmark;
Skateholm, Sweden) into the Eastern Baltic (e.g., Zvejnieki, Latvia; Spiginas and Donkalnis, Lithuania), Karelia, and the Russian Plain (e.g., Oleni Ostrov and Minino, Russia). In respect to the more general patterns in hunter-gatherer anthropology, this intensification in structured mortuary practices can be understood as connected to an increased territoriality and associated economic intensification, e.g., in the exploitation of aquatic resources (Nilsson Stutz 2014). Similar developments can also be noted among prehistoric hunter-gatherers in other parts of the world, e.g. in Japan (Matsumoto, Habu 2017), Transbaikalian Siberia (Weber, Bettinger 2010), and the near East (Byrd, Monahan 1995).

Structurally connected to the increased territoriality is the frequent location of the mortuary sites at elevated or otherwise prominent locations. The famous cemetery of Oleni Ostrov in Karelia, for example, occupies an island in Lake Onega, the Lithuanian sites of Donkalnis and Spiginas are likewise located on islands, and the Hoëdic and Téviec burial sites in France were located at prominent high points at the coastal plain in the Mesolithic (Schulting 1996, p. 336); later hunter-fisher burial sites of communities existing parallel to farmers also fit this rule (e.g., Ostorf, Germany; Lübke et al. 2007). Firmly entwined in the enculturated landscapes with their webs of meaning, history, and significance, the cemeteries can be regarded as transition places in the cosmology of the local hunter-gather groups, as has also been suggested for other locations, e.g. Oleni Ostrov and Skateholm (cf. Nilsson Stutz 2014, pp. 720721). Within the (mobile) lifestyles, they would have served as territorial focus points for social entities.

Groß Fredenwalde, with its occupation of the highest rise in the region, is an impressive example for this pattern (see Fig. 1). Until now there is no evidence of an adjacent contemporary Mesolithic settlement in Groß Fredenwalde and it is likely that the morainic hill was an area reserved especially for ritual activities. The distinguished elevated position of 
the Groß Fredenwalde site indicates a territoriality of a forager group and the authors suggest the existence of a nearby stable settlement network belonging to this group. The territoriality of late hunter gatherers in this region is especially worth investigating as early LBK farmers moved into fertile Uckermark soils from the late 6 th millennium onwards and the upright male (feature 1/4) buried here was possibly a resumption of a territorial hunter-gatherer tradition.

The two phases of use of the Groß Fredenwalde Weinberg hill for hunter-gatherer burials (1: late $7^{\text {th }} /$ early $6^{\text {th }}$ millennium cal BC; 2 : early $5^{\text {th }}$ millennium cal $\mathrm{BC}$, currently represented by only one burial) resembles the situation at the two island cemeteries of Donkalnis and Spiginas in Lithuania, where an initial burial phase around $6000 \mathrm{cal} \mathrm{BC}$ was followed by a hiatus of roughly one thousand years before further burials took place. In contrast, even larger Mesolithic cemeteries seem to be restricted to a shorter period of use, as has been recently demonstrated for Oleni Ostrov (Schulting 2019). Here, a connection with the $8.2 \mathrm{ka}$ climatic cooling event is taken into consideration as a possible trigger for related socio-cultural and economic change, and the chronological position of the earlier phase of the Groß Fredenwalde cemetery broadly fits such a scenario, too. The Latvian site of Zvejnieki is an exception here with its longer history of hunter-gatherer burials (Larsson, Zagorska 2006).

\section{Mortuary practices}

Parallels have been drawn between the Groß Fredenwalde discovery of a multiple and a double burial with burials from Southern Scandinavia (Brinch Petersen 1988; Gramsch, Schoknecht 2003), but such instances are not exclusively connected with the Mesolithic of the North. Mesolithic double and multiple burials are not frequent, but nonetheless they are regularly encountered in cemeteries and also as isolated burials across Europe (Grünberg 1996; Tõrv 2018, pp. 214-222). Sites with such burials include e.g.
Henriksholm-Bøgebakken in Denmark, Zvejnieki in Latvia, and Oleni Ostrov in Russia, but also sites in Western Europe in Téviec, France, and the shell midden in Moita de Sebastião, Portugal. While the famous multiple burial at Strøby Egede, Denmark, is known as a single burial feature, it had also been part of the larger, now destroyed, Ertebølle cemetery (Brinch Petersen 1988). The death of two or more persons at the same time is an exceptional event that can be due to several reasons. There are certainly double or multiple burials where trauma or weapons point to the violent death of those individuals at the same time. More typical are double and multiple burials where an anthropological analysis is unable to detect any cause of death, which could have been the result of an infectious disease, famine, or certain types of accidents.

Mesolithic burial sites and cemeteries across Europe are characterized by a wide variety of different body positions and orientations: supine, crouched and sitting positions, and prone inhumations are frequently encountered (e.g. at Skateholm, Sweden; Oleni Ostrov, Russia), sometimes even supplemented with cremations (Nilsson Stutz 2014; Grünberg 2016). At Groß Fredenwalde, the prevailing body position of the adults seems to have been supine while slightly leaning to the left with strongly crouched legs (Fig. 2-3); upper legs extended downwards, calves are bent. The only clear exception is the later burial of the young man (feature 1/4) in an upright position, which is connected with a complex, multi-phase burial rite. The closest parallels for such an unusual body placement can be found at Oleni Ostrov where four individuals were placed in the grave pits in a near-vertical position, among them also the burial with the richest grave goods (burials 68, 100, 123, 125; Gurina 1956, p. 31; O'Shea, Zvelebil 1984). While these parallels between the famous Karelian huntergatherer cemetery and Groß Fredenwalde are striking, a direct comparison is hindered by the chronological difference of roughly 1000 years. 


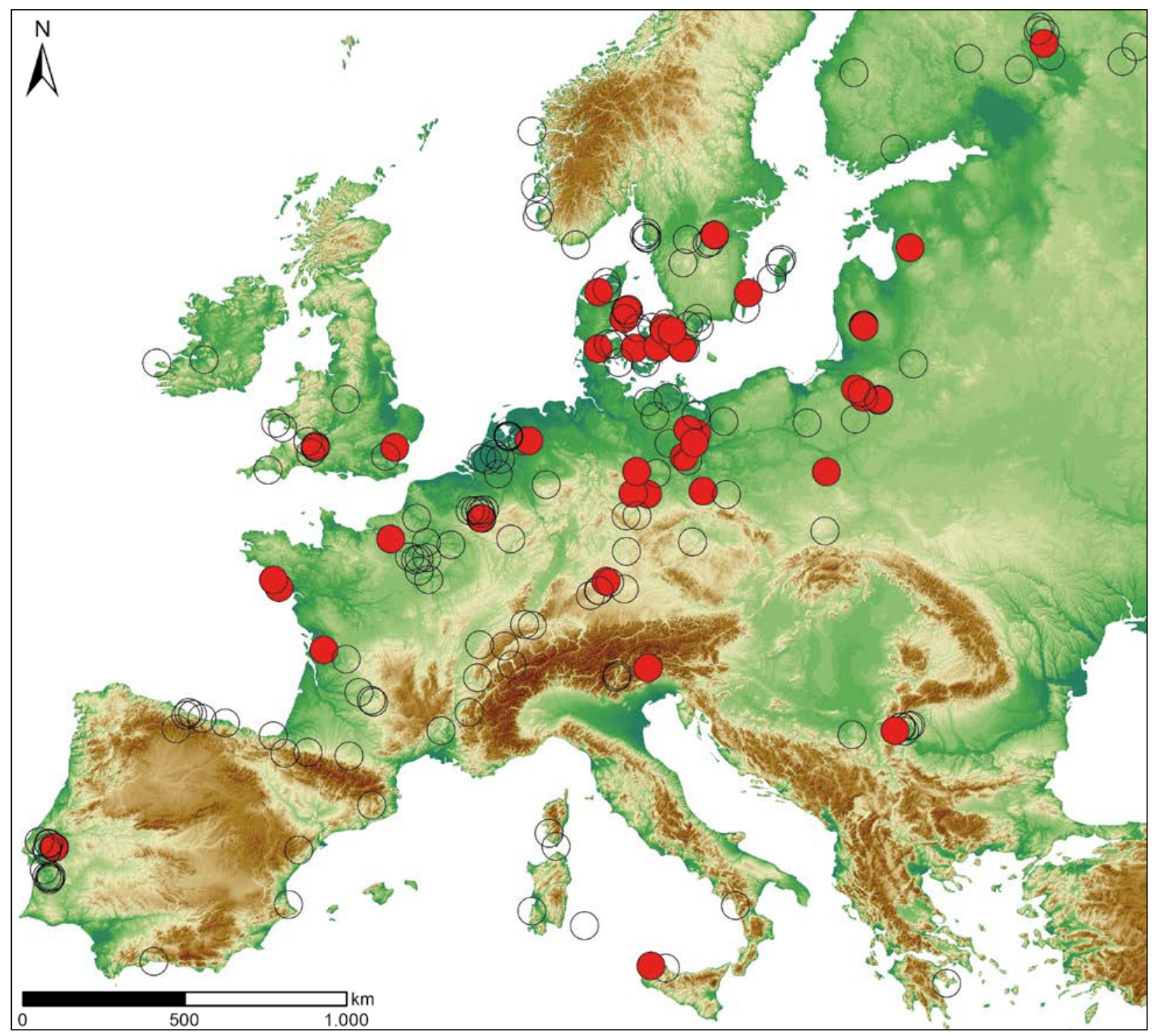

Fig. 7. Flint blades in Mesolithic burials (red=present; transparent=absent). Drawing by A. Kotula.

In most of the Groß Fredenwalde burials, ochre was part of the ritual and the pigment is considered typical for Mesolithic burials (Grünberg 2000). Ochre was commonly used in Northern and Eastern Europe and the large cemeteries at Zvejnieki and Oleni Ostrov are prime examples of the abundant use of ochre in burials. In Western Europe, ochre was also used, e.g. at the Breton sites of Téviec and Hoëdic, but to a much lesser degree (Grünberg 2000, pp. 144ff). Ochre is also a common feature in Mesolithic burials found in
Eastern Germany, e.g. Bad Dürrenberg and Schöpsdorf, while in Southern Germany, only the skull depositions from Große Ofnet and Kaufertsberg bear traces of this pigment (Grünberg 2000; Orschiedt 2015).

\section{Grave goods}

Regional identities can be reflected in grave goods. The homogeneity of animal tooth pendants from Groß Fredenwalde is remarkable: of the 86 


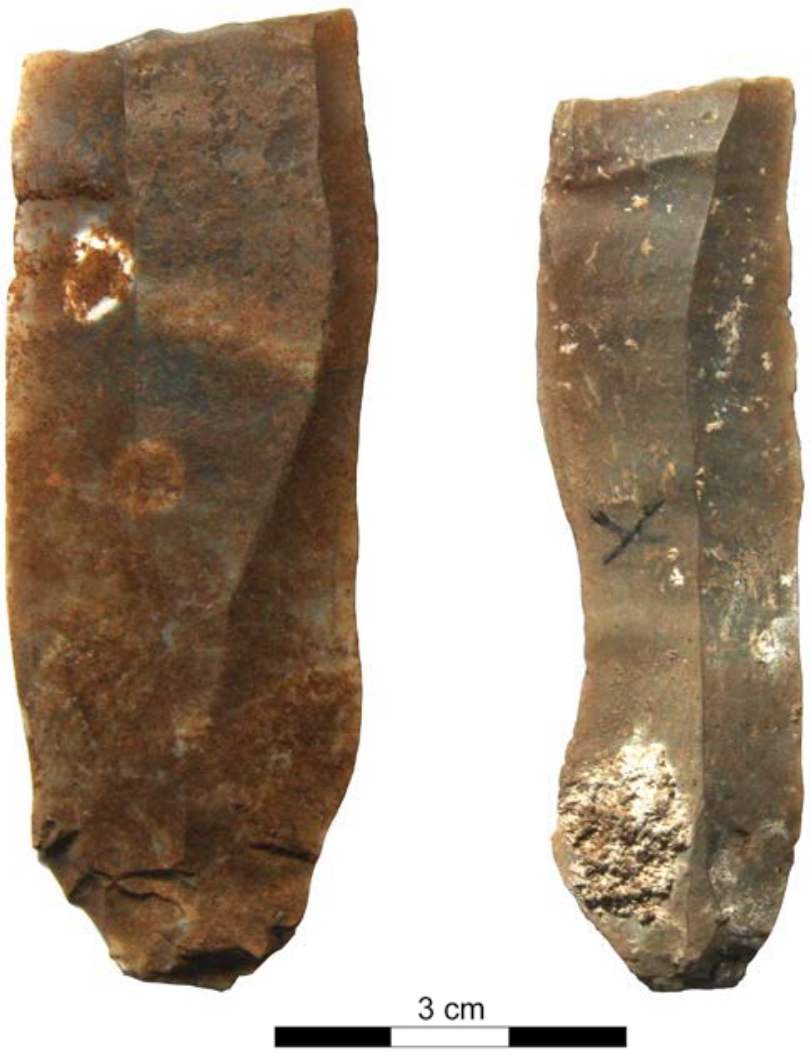

Fig. 8. Groß Fredenwalde. Two truncated blades found in association with the human remains of a young male (feature $1 /$ 4). Photo by A. Kotula.

pendants 41 have so far been identified and all are from red deer. Naturally, the species of tooth pendants is determined by the regional environment and in Eastern Europe, elk, bear, and beaver are especially frequent (e.g. at Oleni Ostrov: Gurina 1956, pp. 134-142). The distribution of red deer pendants, on the other hand, is densest in Southern Scandinavia, but the discovery of such pendants at sites from the Atlantic coast (Téviec and Hoëdic) to the Eastern Baltic (e.g., Donkalnis and Spiginas, Lithuania) attests to their wider distribution (Butrimas 2016). In the Mediterranean and the Atlantic coast, adornments are dominated by shell pendants (Grünberg 2000, p. 118). Due to the specific excavation circumstances at Groß Fredenwalde many of the tooth pendants cannot be attributed to specific individuals. However, the adornment of the head of one of the children
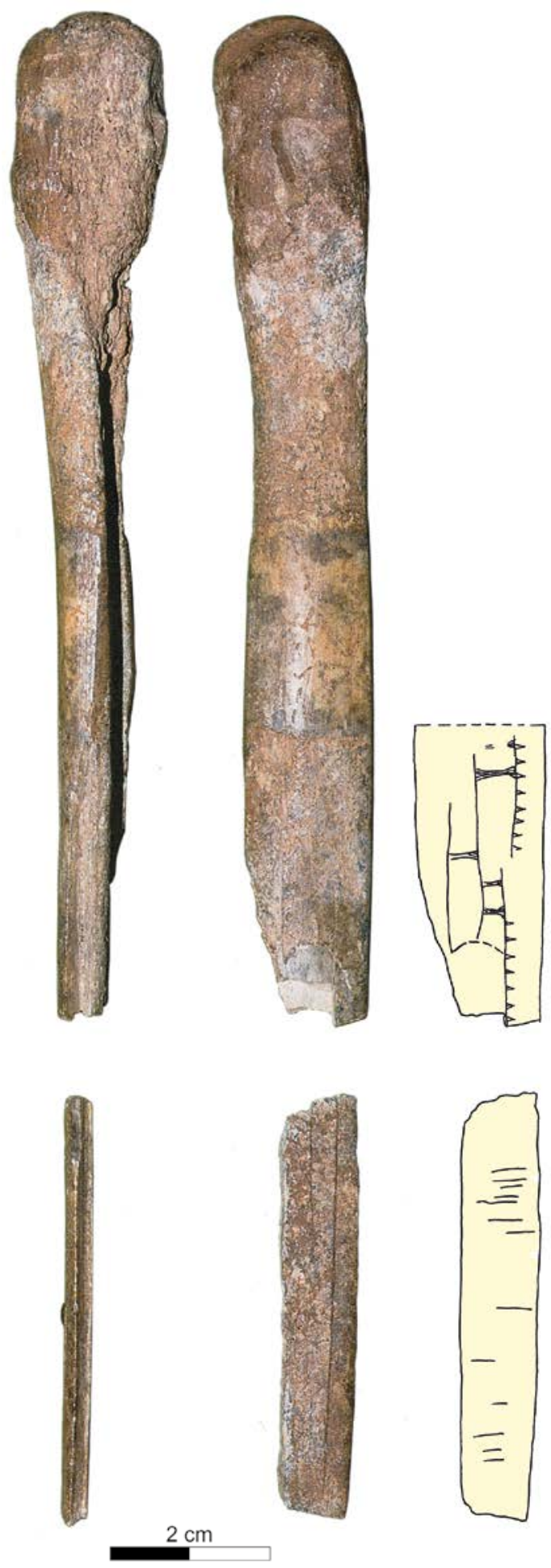

Fig. 9. Groß Fredenwalde. Fragments of a slotted bone dagger probably found with the human remains of complex I in 1962 (after Gramsch, Schoknecht 2003). 


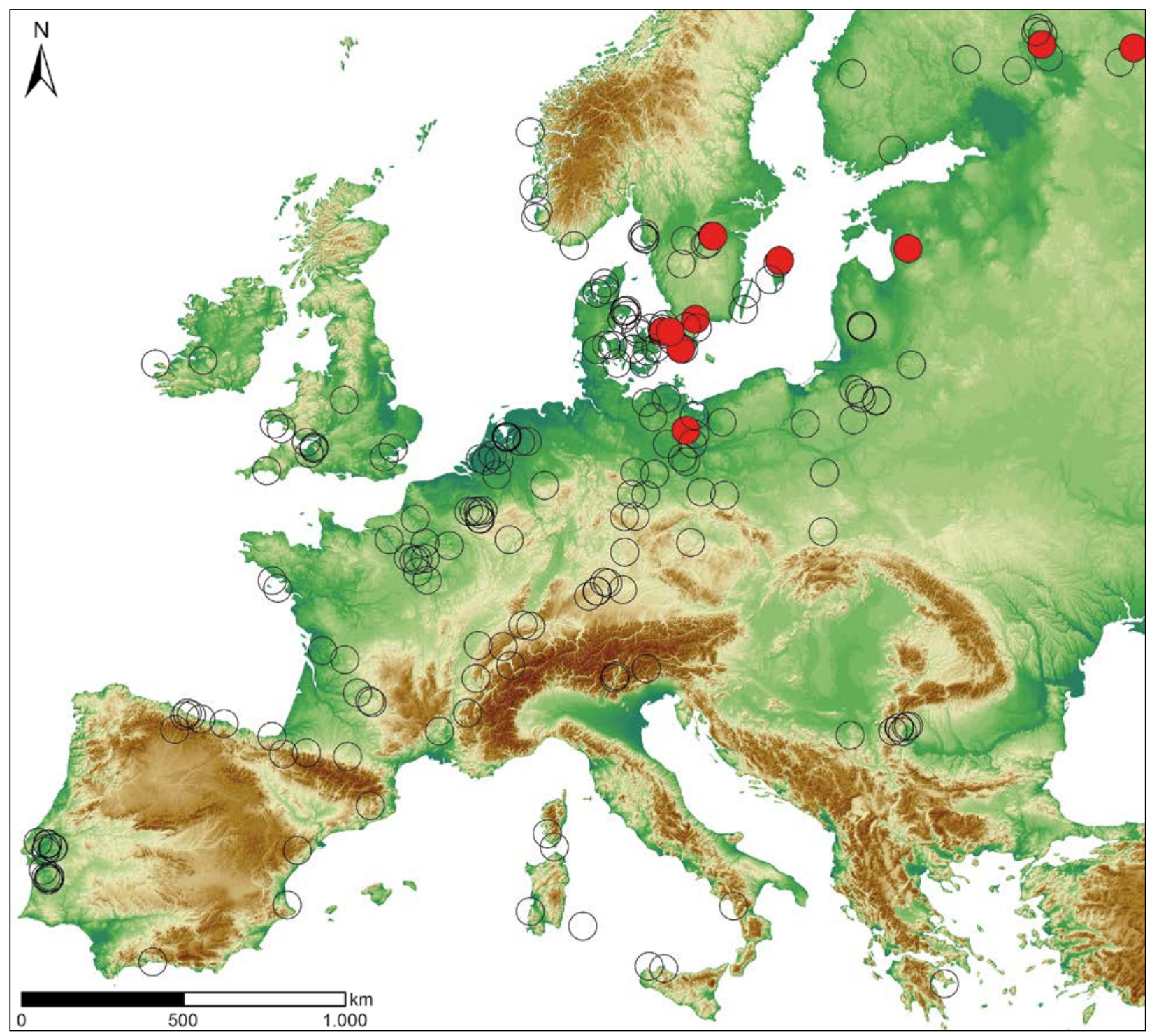

Fig. 10. Slotted bone tools / daggers in Mesolithic burials (red=present; transparent=absent). Drawing by A. Kotula .

(individual 6) with a row of tooth pendants has been recorded in a photo. Such an arrangement indicating decorated headgear has parallels e.g. further east at Donkalnis, Lithuania, and the Karelian site of Oleni Ostrov (Butrimas 2016, p. 210).

While the distribution of flint blades as grave goods in Mesolithic burials is broad, ranging from the Iberian Atlantic coast in the west to Karelia in the East, the flint-rich area of Southern Scandinavia and parts of Northern and Central Germany are especially well represented. This may hint at contacts between the Southern Baltic Coast and the continental plains further south (Fig. 7). The presence of large truncated blades (knives) as grave goods has been especially reported from Danish sites such as HenriksholmBøgebakken and Strøby Egede (Albrethsen, Brinch Petersen 1976; Brinch Petersen 1988), but parallels have also been mentioned from sites like Bottendorf in Germany (Albrethsen, Brinch Petersen 1976). Truncated flint blades in Eastern German burials 
often represent larger specimens that are roughly 1.5$2 \mathrm{~cm}$ in width. In Groß Fredenwalde two truncated blades of remarkable size (Fig. 8) were associated with the individual buried upright (feature 1/4). A nonlocal origin can be expected for at least the $3.2 \mathrm{~cm}$ wide specimen, which may well have been imported from northern flint sources, e.g. Rügen Island.

Another grave good possible to discuss here is a fragmented slotted dagger with some decoration that was found at Groß Fredenwalde in 1962 (Fig. 9). Slotted bone tools with flint insets are a rare but well defined Mesolithic artefact type with a main distribution in the Northeast. The specimen found at Groß Fredenwalde marks the south-western limit of the distribution of this tool type in burials (Fig. 10), which confirms an integration of the site into a north-eastern network. Apart from a cluster in southern Scandinavian, this artefact type occurs in burials in the Eastern Baltic, across Karelia, and into the far Northeast of Europe. There is also a chronological trajectory within this distribution pattern if the radiocarbon dates from these sites are compared, suggesting a dispersal of slotted bone tools with microblade insets from East to West.

\section{CONCLUSIONS - NORTHERN AND EASTERN CONTACTS IN THE ATLANTIC PERIOD}

A preliminary evaluation of the Groß Fredenwalde Mesolithic cemetery indicates its integration into wider cultural networks connected to the North and East. This is reflected, for example, in the grave goods. Analogies for the headdress with animal tooth pendants belonging to a child (individual 6) can be found in eastern Mesolithic burials (see above). The slotted bone tool dated to c. $6000 \mathrm{cal} \mathrm{BC}$ finds parallels in southern Scandinavia and north-eastern Europe. Slotted bone artefacts and the related microblade technology have their origin in Eurasia and this technology spread from the Eastern
European Plain into the western Baltic in the Early Atlantic period (Hartz et al. 2010; Sørensen et al. 2013; Gronenborn 2017; Apel et al. 2018). In accordance with this, trajectories have been put forward for the Late Mesolithic with the identification of the EastWest dispersal of forager pottery, which reached the Southern and western Baltic in the Early Atlantic period (e.g. Piezonka 2015; Jordan et al. 2016; Kotula 2017) and it has become clear that Mesolithic innovation processes in North Central Europe were repeatedly driven by Eastern impetuses.

The youngest burial at Groß Fredenwalde dates to c. $4900 \mathrm{cal}$ вС with the unusual burial rite involving an upright body position also having its closest parallels in the East. However, the four burials with a similar body position at the site of Oleni Ostrov are hundreds of years older and, therefore a direct affiliation seems questionable. It might rather represent a more general reflection of the stark diversity in body positions and mortuary rights that characterize hunter-gatherer burials in Late Mesolithic Europe, with a possible affiliation to specific Eastern traditions. At the same time, there is little doubt that the large truncated flint blades of the upright burial (feature 1/4) strongly suggest direct contacts with the coastal area about $100 \mathrm{~km}$ to the North and the network that existed at that time in the western Baltic Ertebølle Culture.

While these northern and eastern connections appear especially tangible in Groß Fredenwalde, the site was supposedly also affected by underlying, more general communication and innovation networks in the Mesolithic, expanding in longue durée processes from the Northeast. The Groß Fredenwalde Mesolithic cemetery is located on the south-western periphery of this influence network and ongoing archaeological, anthropological, and palaeogenetic research will help to further disentangle the complex amalgamation of north-eastern Mesolithic innovation processes with the incoming Southern farming groups in the Northern lowlands. 


\section{Acknowledgement}

The interdisciplinary research project is financially supported by the Deutsche Forschungsgemeinschaft (TE 259/17-1; PI 1129/3-1).

\section{REFERENCES}

Albrethsen, S. E., Petersen, E. B., 1976. Excavation of a Mesolithic cemetery at Vedbæk, Denmark. Acta Archaeologia, 47, 1-8.

Apel, J., Glørstad, H., Knutsson, K., Knutsson, H., 2018. The Early Settlement of Northern Europe: Technology and Communication. In: Knutsson, K., Knutsson, H., Apel, J., Glørstad, H., eds. Technology of Early Settlement in Northern Europe. Transmission of Knowledge and Culture (=The early settlement of Northern Europe, 2). Sheffield, South Yorkshire: Equinox, 1-22.

Bramanti, B., Thomas, M. G., Haak, W., Unterlaender, M., Jores, P., Tambets, K., AntanaitisJacobs, I., Haidle, M., Jankauskas, R., Kind, C.-J., Lueth, F., Terberger, T., Hiller, J., Matsumura, S., Forster, P., Burger, J., 2009. Genetic discontinuity between local hunter-gatherers and Central Europe's first farmers. Science, 326 (5949), 137-140.

Brinch Petersen, E., 1988. Ein mesolithisches Grab mit acht Personen von Strøby Egede, Seeland. Archäologisches Korrespondenzblatt, 18, 121-125.

Brinch Petersen, E., 2015. Diversity of Mesolithic Vedboek (=Acta Archaeologica, 86, I). Oxford: Wiley.

Butrimas, A., 2016. Biržulis lake islands Donkalnis and Spiginas Mesolithic cemeteries (West Lithuania). In: Grünberg, J. M., Gramsch, B., Larsson, L., Orschiedt, J., Meller, H., eds. Mesolithic burials - Rites, symbols and social organization of early postglacial communities (=Tagungen des Landesmuseums für Vorgeschichte Halle (Saale) 13). Halle (Saale): Landesamt für Denkmalpflege und Archäologie Sachsen-Anhalt - Landesmuseum für Vorgeschichte Halle (Saale), 193-217.
Byrd, B. F., Monahan, C. M., 1995. Death, mortuary ritual, and Natufian social structure. Journal of Anthropological Archaeology, 14, 251-287.

Czekaj-Zastawny, A., Rauba-Bukowska, A., Kukułka, A., Kufel-Diakowska, B., LityńskaZając, M., Moskal-del Hoyo, M., Wilczyński, J., 2020. The earliest farming communities north of the Carpathians: The settlement at Gwoździec site 2. PLOS One, 15 (1), e0227008. https://doi.org/10.1371/ journal.pone.0227008.

Fernandes, R., Grootes, P., Nadeau, M.-J., Nehlich, O., 2015. Quantitative diet reconstruction of a Neolithic population using a Bayesian mixing model (FRUITS): the case study of Ostorf (Germany). American Journal of Physical Anthropology, 158 (2). https://doi.org/10.1002/ajpa.22788.

Gramsch, B., 2016. The Mesolithic burials of north-eastern Germany: Synopsis and new aspects. In: Grünberg, J. M., Gramsch, B., Larsson, L., Orschiedt, J., Meller, H., eds. Mesolithic burials - Rites, symbols and social organization of early postglacial communities (=Tagungen des Landesmuseums für Vorgeschichte Halle (Saale) 13). Halle (Saale): Landesamt für Denkmalpflege und Archäologie Sachsen-Anhalt - Landesmuseum für Vorgeschichte Halle (Saale), 385-400.

Gramsch, B., Schoknecht, U., 2003. Groß Fredenwalde, Lkr. Uckermark - eine mittelsteinzeitliche Mehrfachbestattung in Norddeutschland. Veröffentlichen zur brandenburgischen Landesarchäologie, 34, 9-38.

Gronenborn, D., 2017. Migrations before the Neolithic? The Late Mesolithic blade-and-trapeze horizon in central Europe and beyond. In: Meller, H., Daim, F., Krause, J., Risch, R., eds. Migration and Integration from Prehistory to the Middle Ages (=Tagungen des Landesmuseums für Vorgeschichte Halle (Saale) 17). Halle (Saale): Landesamt für Denkmalpflege und Archäologie Sachsen-Anhalt - Landesmuseum für Vorgeschichte Halle (Saale), 113-127.

Grote, K., Terberger, T., 2011. Die prähistorischen Kinderbestattungen vom Abri Bettenroder Berg IX 
im Reinhäuser Wald bei Göttingen. Archäologisches Korrespondenzblatt, 41, 189-195.

Grünberg, J.M., 1996. Burial goods and social structure in Mesolithic Europe. In: Otte, M., ed. Nature et culture: actes du colloque international de Liège, 13-17 décembre 1993. Liège Univ., 899-912.

Grünberg, J. M., 2000. Mesolithische Bestattungen in Europa. Ein Beitrag zur vergleichenden Gräberkunde (=Internationale Archäologie 40). Rahden, Westfalen: Verlag Marie Leidorf GmbH.

Grünberg, J., 2016. Mesolithic burials - Rites, symbols and social organization of early postglacial communities. In: Grünberg, J. M., Gramsch, B., Larsson, L., Orschiedt, J., Meller, H., eds. Mesolithic burials - Rites, symbols and social organization of early postglacial communities (=Tagungen des Landesmuseums für Vorgeschichte Halle (Saale) 13). Halle (Saale): Landesamt für Denkmalpflege und Archäologie Sachsen-Anhalt - Landesmuseum für Vorgeschichte Halle (Saale), 13-24.

Grünberg, J., Graetsch H.A., Heußner, K.U., Schneider, K., 2016. Analyses of Mesolithic grave goods from upright seated individuals in Central Germany. In: Grünberg, J. M., Gramsch, B., Larsson, L., Orschiedt, J., Meller, H., eds. Mesolithic burials - Rites, symbols and social organization of early postglacial communities (=Tagungen des Landesmuseums für Vorgeschichte Halle (Saale) 13). Halle (Saale): Landesamt für Denkmalpflege und Archäologie Sachsen-Anhalt - Landesmuseum für Vorgeschichte Halle (Saale), 291-328.

Hartz, S., Lübke, H., Terberger, T., 2007. From fish and seal to sheep and cattle - new research into the process of neolithization in northern Germany. In: Whittle, A., Cummings, V., eds. Going over: The Mesolithic-Neolithic transition in North-West Europe. London: British Academy, 567-594.

Hartz, S., Terberger, T., Zhilin, M., 2010. New AMS-dates for the Upper Volga Mesolithic and the origin of microblade technology in Europe. Quartär, 57, 155-169.
Hedges, R. E. M., Housley, R. A., Bronk Ramsey, C., Klinken, G. J., 1995. Radiocarbon dates from the Oxford AMS system: Archaeometry datelist 19. Archaeometry, 37 (1), 195-214.

Hofmanová, Z., Kreutzer, S., Hellenthal, G., Sell, Ch., Diekmann, Y., Díez-del-Molino, D., van Dorp, L., et al. 2016. Early farmers from across Europe directly descended from Neolithic Aegeans. PNAS, 13 (25), 6886-6891. https://doi.org/10.1073/ pnas. 1523951113.

Ismail-Weber, M. I., 2017. ...100 km from the next settlement... Mobility of Linear Pottery Groups in Brandenburg, North-Eastern Germany. In: Scharl, S., Gehlen, B., eds. Mobility in Prehistoric Sedentary Societies. Papers of the CRC 806 Workshop in Cologne 26-27 June 2015. (=Kölner Studien zur Prähistorischen Archäologie 8). Rahden /Westfalen: Marie Leidorf, 75-117.

Jordan, P., Gibbs, K., Hommel, P., Piezonka, H., Silva, F., Steele, J., 2016. Modelling the Diffusion of Pottery Technologies across Afro-Eurasia: Emerging Insights and Future Research Questions. Antiquity, 90, 590-603.

Jungklaus, B., Terberger, T., 2016. Baby im Grab. Älteste Bestattung Brandenburgs in Groß Fredenwalde, Lkr Uckermark. Archäologie in Berlin und Brandenburg, 31-34.

Jungklaus, B., Kotula, A., Terberger, T., 2016. New investigations into the Mesolithic burial of Groß Fredenwalde, Brandenburg - first results. In: Grünberg, J. M., Gramsch, B., Larsson, L., Orschiedt, J., Meller, H., eds. Mesolithic burials - Rites, symbols and social organization of early postglacial communities (= Tagungen des Landesmuseums für Vorgeschichte Halle (Saale) 13). Halle (Saale): Landesamt für Denkmalpflege und Archäologie Sachsen-Anhalt - Landesmuseum für Vorgeschichte Halle (Saale), 419-433.

Kotula, A., 2017. Dersteinzeitliche Seeuferfundplatz Dąbki, Pommern (Polen) - Fundplatzstruktur und mesolithische Keramik im nordmitteleuropäischen Kontext. Unpublished doctoral thesis, Göttingen University. 
Larsson, L., Zagorska, I., eds., 2006. Back to the origin: new research in the Mesolithic-Neolithic Zvejnieki cemetery and environment, northern Latvia (=Acta Archaeologica Lundensia, 52). Lund University.

Lübke, H., Lüth, F., Terberger, T., 2007. Fishers or farmers? The Archaeology of the Ostorf Cemetery and Related Neolithic Finds in the Light of New Information. Berichte der Römisch-GermanischenKommission, 88, 307-338.

Marciniak M., 2001. The burial ritual from the boreal period cemetery in Mszano, Brodnica District. Fontes Archeologici Posnaniensis, 39, 95-123.

Matsumoto, N., Habu, J., 2017. Subsistence, sedentism, and social complexity among Jomon hunter-gatherers of the Japanese Archipelago. In: Habu, J., Lape, P. V., Olsen, J. W., eds. Handbook of East and Southeast Asian archaeology. New York: Springer-Verlag, 437-450.

Meiklejohn, C., Brinch Petersen, E., Babb, J., 2009. From single graves to cemeteries: an initial look at chronology in Mesolithic burial practice. In: McCartan, S., Schulting, R., Warren, G., Woodman, P., eds. Mesolithic Horizons. Papers presented at the Seventh International Conference on the Mesolithic in Europe, Belfast, 2005. Oxbow Books, 639-649.

Müller, J., 2011. Early Pottery in the North A Southern Perspective. Berichte der RömischGermanischen Kommission, 89, 287-299.

Nilsson Stutz, L., 2014. Mortuary Practices. In: Cummings, V., Jordan, P., Zvelebil, M., eds. The Oxford Handbook of the Archaeology and Anthropology of Hunter-Gatherers. Oxford University Press, 712-728.

Olsen, J., Heinemeier, J., Lüth, F., Lübke, H., Terberger, T., 2010. Dietary habits and freshwater reservoir effects in bones from a Neolithic NE German cemetery. Radiocarbon, 52, 2, 635-644.

Orschiedt, J., 2015. Die Große Ofnet-Höhle: Ein steinzeitliches Massaker? In: Meller, H., Schefzik, M., eds. Krieg. Eine archäologische Spurensuche. Exhibition catalogue. Landesmuseum Halle (Saale). Halle (Saale): Landesamt für Denkmalpflege und
Archäologie Sachsen-Anhalt - Landesmuseum für Vorgeschichte Halle (Saale), 99-102.

O’Shea, J., Zvelebil, M., 1984. Oleneostrovski mogilnik: Reconstructing the Social and Economic Organization of Prehistoric Foragers in Northern Russia. Journal of Anthropological Archaeology, 3, 1-40.

Piezonka, H., 2015. Jäger, Fischer, Töpfer. Wildbeuter mit früher Keramik in Nordosteuropa im 6. und 5. Jahrtausend v. Chr. (=Archäologie in Eurasien 30). Bonn: Habelt-Verlag.

Rimantienè, R., 1994. Die Steinzeit in Litauen. Berichte der Römisch-Germanischen Kommission, 75, 23-146.

Schoknecht, U., 1963. Neolithische Flachgräber von Groß Fredenwalde, Kr. Templin. Ausgrabungen und Funde, 8, 173-178.

Schulting, R., 1996. Antlers, bone pins and flint blades: The Mesolithic cemeteries of Téviec and Hoëdic, Brittany. Antiquity, 70, 335-350.

Schulting, R., 2019. The long and short of it: the temporality of burial in the large cemeteries of Lake Baikal and northeast Europe. Paper presented at the International Open Workshop "Socioenvironmental dynamics over the last 15,000 years: The creation of Landscapes VI". Kiel University, March 11-16, 2019.

Schwabedissen, H., 1994. Die Ellerbek-Kultur in Schleswig-Holstein und das Vordringen des Neolithikums über die Elbe nach Norden. In: Hoika, H., Meurers-Balke, J., eds. Beiträge frühneolithischen Trichterbecherkultur im westlichen Ostseegebiet. Untersuchungen und Materialien zur Steinzeit im Schleswig-Holstein und im Ostseeraum 1. Neumünster: Wachholtz, 361-401.

Sørensen, L., 2014. From Hunter to Farmer in Northern Europe. Migration and Adaptation during the Neolithic and Bronze Age (=Acta Archaeologica, 85, I-III). Oxford: Wiley.

Sørensen, L., Karg, S., 2014. The expansion of agrarian societies towards the north - new evidence for agriculture during the Mesolithic/Neolithic 
transition in Southern Scandinavia. Journal of Archaeological Science, 51, 98-114.

Sørensen, M., Kankaanpää, J., Knutsson, K., Knutsson, H., Melvold, S., Eriksen, B.V., Glørstad, H., 2013. The first eastern migrations of people and knowledge into Scandinavia. Evidence from studies of Mesolithic technology, $9^{\text {th }} 8^{\text {th }}$ Millennium BC, Norwegian Archaeological Review, 46, 19-56.

Terberger, T., Kotula, A., Lorenz, S., Schult, M., Burger, J., Jungklaus, B., 2015. Standing upright to all eternity - The Mesolithic burial site at Groß Fredenwalde, Brandenburg (NE Germany). Quartär, 62, 133-153.

Terberger, T., Burger, J., Lüth, F., Müller, J., Piezonka, H., 2018. Step by step - The Neolithisation of Northern Central Europe in the light of stable isotope analyses. Journal of Archaeological Science, 99, 66-86.
Terberger, T., Kotula, A., Jungklaus, B., Piezonka, $\mathrm{H}$., in press. The Mesolithic "multiple burial" of Groß Fredenwalde revisited. In: Jöris, O., et al. eds. Festschrift for Elaine Turner and Martin Street.

Tõrv, M., 2018. Persistent Practices. A multidisciplinary study of hunter-gatherer mortuary remains from c. 6500-2600 cal. BC, Estonia (= Untersuchungen und Materialien zur Steinzeit in Schleswig-Holstein und im Ostseeraum 9). Kiel, Hamburg: Wachholtz Verlag - Murmann Publishers.

Weber, A., Bettinger, R. L., 2010. Middle Holocene hunter-gatherers of Cis-Baikal, Siberia: an overview for the new century. Journal of Anthropological Archaeology, 29 (4), 491-506.

Гурина, Н. Н., 1956. Оленеостровский могильник (=Материаль и исследования по археологии СССР, 47). Москва, Ленинград: Издат. Акад. Наук СССР.

\title{
GROS FREDENVALDE (ŠIAURĖS RYTŲ VOKIETIJA) MEZOLITO LAIKOTARPIO KAPINYNAS IR JO KULTŪRINĖS SĄSAJOS
}

\author{
Andreas Kotula, Henny Piezonka, Thomas Terberger
}

\section{Santrauka}

Gros Fredenvalde kapinynas atrastas 1962 metais. $1990 \mathrm{~m}$. radioaktyviąja anglimi atlikti tyrimai patvirtino, jog žmonių palaikų amžius siekia mezolito laikotarpi. Tyrimai buvo atnaujinti 2012 m.: nuosekliai kasinèta $1962 \mathrm{~m}$. tirta duobè. Taip pat buvo atlikta sistemiška žmonių palaikų, rastų 1962 m., analizè, identifikuoti šeši asmenys. Su šiais palaidojimais siejamos ịkapès - titnaginès skeltès, skersiniai strèlių antgaliai, sudètinio tipo durklo fragmentai ir žvèrių dantų pakabukai. Negana to, archyvuose buvo aptikta nuotraukų iš tų pačių metų - jos taip pat žymiai prisidejjo prie visapusiškesnio medžiagos supratimo. Šioje medžiagoje matyti mažiausiai du grupiniai palaidojimai, aiškiai išsiskiriantys tiek erdviškai, tiek pagal kapų orientaciją.
Besitęsiantys tyrimai patvirtina, kad $1962 \mathrm{~m}$. radiniai yra dalis kapinyno su kitais - pavieniais ar grupiniais - kapais. Kapas, kuriame apipiltas ochra palaidotas vienerių metų vaikas, rastas greta $1962 \mathrm{~m}$. tirtos duobès (datuojamos apie $6430 \mathrm{cal} \mathrm{BC).}$

Kitame kapų komplekse rasti dviejų žmonių, palaidotų tūkstančio metų intervalu, kapai. Vienas maždaug 8-9 metų vaikas (apie 5940 cal BC). Tačiau didžioji dalis šio kapo buvo suardyta vèlesnio palaidojimo: apie 4900 cal BC toje vietoje iki pusès, atliekant nuoseklius ritualus, stačiomis buvo užkastas apie 25 metų amžiaus vyras. Pastaruoju metu buvo aptikta ir daugiau palaidojimų, taigi šiuo metu vyksta jų fiksavimo darbai. 
Apibendrinant galima teigti, kad Gros Fredenvalde kapinynui priskiriami daugiau nei dešimt asmenų mažiausiai iš aštuonių kapų. Radioaktyviosios anglies datavimas rodo, jog pagrindinis kapinyno naudojimo laikotarpis tęsėsi 6400-5800 cal BC. Iki šiol nerasta jokių įrodymų šalia buvus vienalaikę gyvenvietę. Dèl to svarstoma, kad ši moreninè kalva buvo naudojama tik ritualinèms veikloms.

Mezolito laikotarpio laidojimo vietos ir kapinynai Europoje pasižymi tuo, kad mirusieji būdavo laidojami Ł̇vairiomis pozicijomis ir kryptimis. Gros Fredenvalde kapinyne palaikai dažniausiai guldyti aukštielninki, šiek tiek pasukti ị kairę, suglaustomis suriestomis kojomis. Vienintelè išimtis - anksčiau minètas jauno vyro palaidojimas stačiomis. Dar vienas analogiškas palaidojimas buvo rastas Olenij Ostrovo vietoveje.

Regioninès tapatybės atspindžiai matyti ịkapèse. Štai Gros Fredenvalde kapinyne rastos dvi neiprastai didelès nulaužtos skeltès siejamos su stačiomis palaidotu asmeniu ir, manoma, galèjo būti importuotos iš titnago turtingų vietovių Šiaurèje, pvz., iš Riugeno salos. Sudètinio tipo kauliniai įrankiai su titnaginiais ašmenèliais yra retas, tačiau būdingas mezolito laikotarpiui dirbinų tipas, daugiausiai paplitęs Šiaurès Rytuose. Pavyzdys rastas Gros Fredenvalde kapinyne žymi pietvakarinę šių ịrankių, randamų kapuose, išplitimo ribą.

Preliminarus Gros Fredenvalde mezolito laikotarpio kapinyno vertinimas rodo ji buvus dalimi platesnių kultūrinių ryšių, jungiančių Šiaurę su Rytais. Kapinynas mezolito laikotarpyje taip pat galejo būti veikiamas gilesnių, bendrų komunikacijos ir inovacijų ryšių, besitęsiančių ilgą laiką, Šiaurès Rytų kryptimi. Taigi, Gros Fredenvalde mezolito laikotarpio kapinynas yra pačiame pietvakariniame šių ittakų pakraštyje.

\section{ILIUSTRACIJŲ SĄRAŠAS}

1 pav. Gros Fredenvalde kapinyno vieta Ukermark kraštovaizdyje (Branderburgas, Šiaurès-Rytų Vokietija). A. Kotulos brëž.
2 pav. Gros Fredenvalde kapinyno tyrimų plane (1 ir 2 kompleksai) pažymèti kapai bei 1962-aisias metais surasta konstrukcija su individų palaikais. A. Kotulos brëž.

3 pav. Gros Fredenvalde kapinynas. 1962-ųjų metų nuotraukoje, kuri daryta pirmąją atradimo dieną, pažymèti 1 komplekse išskirti individai. Brandenburgisches Landesamt für Denkmalpflege nuotr.,

A. Kotulos schema.

4 pav. Gros Fredenvalde kapinynas. Objektas 1/4 apie 25 metų amžiaus neaiškioje pozicijoje palaidoto vyro kapas, rastas po ugniaviete. A. Kotulos nuotr.

5 pav. Gros Fredenvalde Objekte 1/4 fiksuoti jauno vyro kojų kaulai, išsidèstę beveik anatominèje padètyje. T. Terbergerio nuotr.

6 pav. Mezolito-neolito chronologijos ŠiaurèsCentrineje Europoje schemoje nurodomas Gros Fredenvalde ir kitų svarbių kapinynų datavimas. Ištisinè linija: radioaktyviosios anglies datavimo metodu nustatytos datos. Brūkšninè linija: numanomas laikotarpis nustatytas atsižvelgiant ị pavienes radioaktyviosios anglies datas ir kitus duomenis. T. Terbergeris ir A. Kotula sud.

7 pav. Titnaginès skeltès rastos mezolito laikotarpio kapuose (raudoni apskritimai: rasta, bespalviai apskritimai: nerasta). A. Kotulos brëž.

8 pav. Gros Fredenvalde. Dvi nulaužtos skeltès siejamos su jauno vyro palaidojimu (objektas 1/4). A. Kotulos nuotr.

9 pav. Gros Fredenvalde. Sudètinio tipo kaulinio durklo fragmentai, greičiausiai rasto su žmogaus palaikais 1-ąjame komplekse, 1962 metais (mastelis 2:3. (Pagal Gramsch, Schoknecht 2003).

10 pav. Sudètinio tipo kauliniai įrankiai / durklai mezolito laikotarpio kapuose (raudoni apskritimai: rasta, bespalviai apskritimai: nerasta). A. Kotulos brëž. 